\title{
Addressing Community in Late Medieval Dalmatia
}

\author{
Oliver Schmitt
}

Community is a social and cultural construct. As such it exists in terminology, discourse and social practice. This paper aims at assessing community both in its terminological/discursive and practical dimension in normative texts and "pragmatische Schriftlichkeit" with particular emphasis on their interrelation with social practice in late medieval Dalmatia. This region is chosen because of the extraordinary density of evidence concerning discourses on normative rules in daily socio-cultural practice. ${ }^{1}$ Norm and practice are not perceived as separate, but as interconnected dimensions of community building. The focus is on socio-cultural processes that trigger change both in normative systems and in the social practice of communities. Norms are constantly constructed and adapted by social actors. But they also have on strong impact on social actions. These actions are analysed here as representations of patterns of belonging and identification. Community is understood as a consciousness of belonging, which was repeatedly visualized in daily social practice, especially in cases of conflict and dissent that activated communitarian solidarity. There were multiple layers of communitarian belonging in late medieval Dalmatian communities, and emphasizing the highly complex fault lines of these societies stands at the core of this paper.

In a first step this paper seeks to address the problem by analysing various late medieval terms which defined and/or circumscribed different types of community in Dalmatia. The analysis starts with normative texts and in a second step integrates examples of "pragmatische Schriftlichkeit". ${ }^{2}$ Community does not only exist where groups are explicitly characterized as "comunitas/ comune/universitas". Community is enacted in social practice. Belonging to a community in daily life is a situative act. Social rituals and conflicts have a particularly huge potential for making patterns of belonging physically visible. A third part of the paper will explore this dimension. Community encompasses

1 For the cultural context of community studies in the Venetian Commonwealth see Muir, "The Idea of Community"; Gentile, "Factions and Parties". The research for this article was funded by the Austrian Science Fund (FWF): F42 Visions of Community.

2 Keller etal., eds., Pragmatische Schriftlichkeit; in particular:GerhardDilcher, "Verschriftlichung und Wandlungen der Normstruktur in den Stadtrechten des 12. und 13. Jahrhunderts", 9-19; Hagen Keller, "Die Veränderung gesellschaftlichen Handelns".

(C) OLIVER SCHMITT, 2016 | DOI 10.1163/9789004315693_007

This is an open access chapter distributed under the terms of the Creative Commons Attribution- 
groups of people, and usually communities are studied as social entities. As a complementary dimension this paper proposes a micro-historical approach. Although the main structure of the paper concentrates on community as a collective entity, it seeks to combine this analysis with the perspective of a single person whose life and deeds are documented in hundreds of documents (protocols, petitions, contracts, testimonies): Zuanin Dragačić (ca. 1410ca.1475) was born as the son of a peasant in the village of Čara; he was to become the leader of the non-patricians, a successful businessman and investor, legal expert, diplomat, confidant of Venetian central authorities, head of a political and social network that encompassed important parts of the island. Dragačić certainly was not a "normal" or average representative of the Korčula peasantry, and the extraordinary documentary density covering his lifespan is due to his socio-political advancement. Nevertheless, he is probably one of the best documented non-noble person in the late Venetian overseas empire.

His life story can be combined with a structural analysis of community building and major changes in the Adriatic world and Dragačićs eminent role in processes of community building will give sense to this approach.

\section{The Socio-Cultural and Legal Context}

\section{Normative Sources}

In the 15th century, Dalmatian urban communities could look back on at least 150 years of written law codification (statuta). ${ }^{3}$ This codification process was part of a general modernization of urban law in Italy and the Adriatic area. Law terminology was therefore well developed and rather sophisticated. The institution which commissioned these codifications was the town, or more exactly those free men who had sworn an oath of loyalty to a comune/comunitas. A commune denoted both a political space and a group of people who inhabited it and possessed the political right to participate in its administration. Comunitas was coined as key term for a socio-political congregation which draws a clear line between members of the community and all others, e.g. peasants in surrounding villages (the so-called contado), but also foreigners, even if they had lived in the community for a longer period. Comunitas and comune thus served as terminological abstractions for a personal network and a clearly defined space, but it also materialized in architecture (city hall, loggia, religious buildings as cathedrals), material culture (e.g. the codex which contained the statute) and socio-cultural practice (assemblies, councils, common

3 Steindorff, Die dalmatinischen Städte; Steindorff, "Privilegien"; Malz, "Frühneuzeitliche Modernisierung". 
defence, e.g. communal police boats, galleys etc.). Traditional research assumed that discourse on this terminology was based on the statutes, i.e. that statutes were composed first and that community virtually emanated from this source. Research on the Dalmatian statutes, mainly by historians of law, often produces a rather static picture of the statutes. Here one has to take into account recent research on Italian and German urban statutes in order to reveal processes of negotiation which eventually led to the final result, the codification of law which moreover was the subject of constant change.

\section{"Pragmatische Schriftlichkeit"}

This paper focuses on one case study, the island of Korčula in southern Dalmatia which was under Venetian rule from $1420 .{ }^{4}$ This example is chosen because of the unusual character of its archival text corpus. The archive of Korčula contains one of the most complete regional archives for the late medieval Mediterranean world. This text corpus was mainly produced on the island, but by different actors: normative texts were usually codified in the preVenetian period and reflect both communal/regional legal traditions and the process of law codification in the late medieval Adriatic area. "Pragmatische Schriftlichkeit" emanates mainly from different administrative bodies on the island which were supervised by Venetian authorities. Although the production of documents virtually exploded after the beginning of Venetian administration, it is unclear if this is to be explained by new administrative methods or by the contingency of archival preservation. Since the transition from preVenetian to Venetian administration was a smooth process in which Venetians played only a minor role, the latter seems the more probable explanation. Indeed, local councils and local administrative bodies continued their work without any major interruption or interference on the part of the Venetian governor. Venetian administrative presence on the island was limited to the person of the governor, his chancellors and two or three servants.

Our text corpus does not constitute a genetic unit: we can distinguish between the chancery of the Venetian governor and texts produced on a more local level, mainly reports of local officers to the Venetian governor. Over a period of roughly 60 years $(1420-80)$ the administration gradually introduced rules of a homogenized central administration, a slow development that is also visible in language, style and structure of many texts. Chancellors accompanied Venetian governors during their two-year term and consequently changed every two years. Despite of this tendency towards a homogenization

4 Orlando, Gli accordi con Curzola; Ortalli, "Il ruolo degli statuti"; Dokoza, Dinamika otočnog prostora; Schmitt, Korčula; id., "Storie d'amore”. 
of "pragmatische Schriftlichkeit", the production of the Venetian chancery does not constitute a purely "foreign" perspective. Local narratives are present both in petitions and protocols of lawsuits. Protocols are the result of a transfer from orality to "Schriftlichkeit", in this case under the control of a foreign (not local) secretary. Whenever testimonies had to be translated from čakav (in the sources usually "lingua sclavonica", "sclavonice") into Italian, the chancellor referred to that process in a special note. Nevertheless, if interpreted carefully, bearing in the mind the process of "filtration", they offer evidence for analysing regional discourses on community and communitarian belonging.

\section{Naming Community: Terminological Concepts of Community}

Late medieval Dalmatian societies possessed a differentiated terminology for labelling and defining communities. This terminology evolved in the wider socio-cultural context of the Italo-Slavic Adriatic area and does not constitute a regional specificity. Key terms are both comune and comunitas, which denote both the above-mentioned personal and territorial unit. Civitas refers more precisely to urban communities, while universitas is often used for rural communities, mainly village communities which encompass both a personal network and a territory. Peasant leaders resorted to this term to denote "the whole people of Korčula" (tuta quela università de popolo de Curzola), which in their eyes was the proper denomination for the non-patricians. ${ }^{5}$ These terms constitute legal terms in the sense that they were used in codified local legal systems, the "statute". Since these statutes were codified in an urban environment, they define urban domination on a rural hinterland as normative political system. The case of Korčula is rather atypical of these socio-cultural structures because of the survival of rural law traditions and even assemblies. Their Slavic term, veće, attested uniquely in Latin texts, points to socio-cultural differences in legal terminology: ${ }^{6}$ although urban and rural groups both belonged to the same linguistic group, a cultural difference was visible in legal terminology between rural/Slavic and urban/Latin. It would however be erroneous to construct two culturally and socially different worlds on an island with a remarkable linguistic and confessional homogeneity: rural political leaders mostly referred to the same set of legal terms as urban political actors didbut as we shall see, not the terms but the meanings given to them were different and the object of contest.

5 DAZ AK 10/14/4, fol. 1 .

6 DAZ AK 7/9/1, fol. 13or.: "veche". 
The title of this paper contains the term "addressing communities" - the semantic field of "addressing" includes naming, labelling, designing, interpreting. We now have to analyse how members of social and political groups approached our key term from various perspectives. To do this we have to categorize this local society into different groups; this follows both contemporary constitutional categories and groups that are constructed for our research design: the island society was divided into people who possessed political rights (who could elect and be elected as members of councils and offices) and those who were excluded from political participation on the level of the entire island, i.e. the Council of Korčula. There were differences in status and wealth within the politically privileged group. The excluded did not constitute a homogenous group either: wealth and status, rural or urban environment, literacy or illiteracy were markers of social difference. Furthermore, formal exclusion did not necessarily imply absence from political life. Participation in public life, i.e. in the island community as political entity was the object of fierce contest. Many men who could not attend the meetings of the Council of Korčula were fully entitled to take part in village assemblies, mainly in the western part of the elongated island. Exclusion is therefore a relative category and concerns only participation in the main island council. It is not by chance that villagers seriously challenged its competence to represent the whole island community.

Addressing community in the sense of defining community, defining rules and delimitations of belonging is, on the contrary, a key pattern of social life in the late medieval Adriatic. Community was addressed in our text corpus both by individuals and by groups, the former case being the more frequent. Analysing individual behaviour should not induce us to postulate a high degree of individuality —individual patterns of addressing community are studied here as expressions a group discourses - and of personal interests, or as Edward Muir puts it, "precepts and practices of community also worked in the opposite direction, transforming and expressing interpersonal conflicts". ${ }^{7}$ The latter have to be reconstructed by a careful analysis of their social position and context. The key question however is how these-social, political, constitutional, economicgroups can be defined. A simple division into politically privileged/non privileged which still dominates research debates can only be a starting point. ${ }^{8}$

\section{Consensual Patterns of Addressing Communities}

Screening our text corpus on the search of terms designing community, one easily comes across a wide range of social, economic and politico-constitutional

7 Muir, "The Idea of Community", 4.

8 Foretić, "Borbe". 
meanings. Persons belonging to all groups outlined above refer to communal institutions (council, offices as the avogadori de comun or state prosecutor, ambassadors of the community), ${ }^{9}$ communal law, communal territories (usually leased by the council), communal roads and the communal loggia.

It is remarkable that religious or ethnic patterns of belonging do not appear in our text corpus at all. The clergy and clergymen emerge predominantly as a social group. This is certainly due to the high degree of ethno-religious homogeneity on a Catholic and čakav-speaking island. But it also depends on text genres: on the neighbouring island of Hvar humanist discourses of Slavic descent and Slavic pride flourished around $1500 .{ }^{10}$ Although the influence of Renaissance discourses is visible in the political language of the island and even in personal names in all social strata (Paris, Hector), ethnicity was completely absent in an otherwise sophisticated political discourse. Focusing on constitutional, political and social layers of belonging is thus a justified approach.

Community thus conveys both a discursive and a material dimension: the latter materialized mainly in the loggia, where public life (conclusion of contracts, business, but also leisure activities as games) had its epicentre. A loggia was perceived as symbol of community life both in the political and the societal dimension - but it also enshrined urban life. The village of Blato possessed a loggia: the villagers thus expressed their aspiration to political and social status, challenging the town/countryside model typical for the late medieval Adriatic space.

Naming community was obviously a rather common discursive act on the island, simply because the term community was included in many expressions denoting important elements of public and everyday life. Community was invoked as the term encompassing the whole island society in cases of emergency: a typical case is the recurrent grain shortages in early spring. In 1440, local judges and the Venetian count decided to stop and unload a grain cargo on the way to Venice. They justified this illegal act by stating "all noblemen and all commoners were shouting Lord, if you release the ship, we will not release it, because you should know that we all will starve"."1 In 1456, two patricians declared to the Venetian governor: "It was we who took this grain cargo and not Your Excellency, and if something should be paid, we will do it all together". ${ }^{12}$ Island people acted in this case as a community of survival. Famine, pirate

$9 \quad$ DAZ AK 6/6/6, fol. 125v.

10 Pribojević, O podrijetlu i zgodama Slavena; on discourses of ethnic identifications see Fine, When ethnicity did not matter.

11 DAZ AK $7 / 10 / 1$, fol. $16 \mathrm{r}$.

12 DAZ AK $15 / 26 / 5$, fol. $6 \mathrm{v}$. 
threats, conflicts with neighbours over the control of fisheries, foreign invasions, but also resistance against certain elements of Venetian rule (mainly Venetian control of the Church) all activated strong mechanisms of loyalty to an island community which in times of peace decomposed quickly into groups competing for political and economic resources and for socio-cultural status.

\section{Dimensions of Dissent}

Late medieval Korčula was the scene of intense internal political strife. It is thus not surprising that consensus on what community meant was limited. We will present some examples which demonstrate fault lines of conflict on the island.

1. The surrender of Korčula to Venice in 1420 was negotiated uniquely by patricians. While other Dalmatian and Friulan towns were conquered by the Signoria manu militari, the Korčulan elite concluded a treaty that guaranteed the local constitutional tradition and even foresaw the election of Venetian governor by the local Korčulan council. It soon became evident that the Korčulan elite wanted to restrict Venetian interference in local affairs; they did everything to curtail the governor's competences by invoking local law and traditions and by developing a discourse which contrasted tyranny with the good old law. In 1426, tax collection by the governor "on the territory of our county and community" was compared to tyranny. ${ }^{13}$ This patrician discourse wasunwillingly_put into social practice when the governor physically attacked a peasant who refused to pay a tax on wine; local people on the spot supported the peasant; the governor addressed the bystanders "Do you see how your governors are treated here?"14 By addressing the bystanders in this way he constructed a difference between himself as representative of the Venetian state and the local society, but he did so in order to claim ties of loyalty.

This obligation of loyalty was soon afterwards contested, this time once again by patricians. In 1428 plague broke out, patricians retreated to the villages, and the governor had to man the walls with foreigners. When a leading patrician wanted to return, entrance was denied to him because of the quarantine. This provoked an exchange of words between the Venetian chancellor and the patrician: "I will shit on your beard of shit. ...You are a tyrant and you want to tyrannize our town. ...I will take revenge." The chancellor responded: "This town is not yours, but it belongs to our most serene domination. It is not me, but our governor and his officers who issued this order for the sake of public

13 DAZ AK 6/6/6, fol. 83r.

14 DAZ AK 6/6/6, fol. $87 \mathrm{v}$. 
welfare". The governor added "I am not a tyrant, and if I were a tyrant, our state would know that, butyou are a tyrant, because you refuse to accept the laws and orders of the state".15 This dispute about political models and patterns of belonging is revealing: two concepts of state and community were clashing. The Venetian governors defends the concept of abstract rule ("domination", the "state", "salus publica") whose representative he is; the patrician equally refers to political categories of the Renaissance (tyranny), but combines it with personal attacks against Venetian officers and a personal claim of possession regarding the urban space. The patrician's challenge to Venetian rule thus also contains the claim to define community and legitimacy of power. This dispute has to be put in the context of Venetian constitutional thinking. In fact, modern historiography characterizes Venice as a "composite state" and as "jurisdictional state" with multiple legal systems coexisting beside one another. The respect for local law systems was even at the very core of Venetian state propaganda. ${ }^{16}$ Communal law and Venetian law were juxtaposed, and both were applied at the same time: in June/July 1442 for instance, the Venetian governor applied Venetian law to condemn a Korčulan patrician who had bought a ship in the port town of Vieste in Apulia, and he resorted to local law against men from Dubrovnik who had illegally cut wood and against a Korčulan who had exported grain from Venetian Albania to Dubrovnik. ${ }^{17}$

\section{Layers of Belonging in the Rural Area}

The patricians' claim to absolute political domination on the island caused several serious upheavals on the part of Korčulan peasants. Conflict lines cut across social and political divides, but once again invoking legitimate rule and legal traditions are key elements of the conflict. In 1439, the village community (universitas) of Blato as political entity defended its village pasture area against the intrusion of a flock whose owner was a patrician and whom they considered as a foreigner since he did not belong to the village community. The villagers explained to the governor: "Do not be astonished that we oppose to our homeland [patria] being subjugated by a single man who against our laws and against all good customs stipulated by our assembly [veće], and by perverting our law" entered the communal pasture grounds. ${ }^{18}$ The villagers accepted only

\footnotetext{
15 DAZ AK 6/6/6, fol. 146r-148r.

16 Povolo, "Liturgies of Violence".

17 DAZ AK 10/13/1, fols. 2 r, $4 \mathrm{r}-\mathrm{v}$.

18 DAZ AK $7 / 9 / 1$, fol. 133v.
} 
the Venetian governor as their judge and refused patrician judges. suspecting them of being biased. "Patria" and "veće" - "homeland" and "assembly" - are the central terms for addressing community: this village community constituted itself as a political, territorial, economic and legal unit with its own system of traditions and values. The "other" was the patrician owner of the flock and his shepherd, who in this discourse of belonging, although they were Korčulans, were both excluded from the village community. The people of Blato also tried to curtail the area of validity of the island statutes. Their attempt at territorializing their communitarian law, however, was eventually rejected by the governor after a scrupulous examination of the island law. Thus he opposed the plan for a legal fragmentation of the island into independent constitutional communities.

The villagers of Blato were certainly the most outspoken advocates of independent rural communities. But the social practice of rural community very often consisted in defending territorial rights, usually in cases of the liability of village communities for damage in their territory. In 1440, the "men of the village" (casale) of Čara declined any responsibility for damage to gardens, theft of agricultural products or burning of fields and justified their behaviour by referring to legal traditions. ${ }^{19}$ Rural communities were also entitled to prosecute crimes on their territory: their policemen (gastaldi) represented the embodiment of rural self-administration at the level of village communities; most cases deal with the theft of cattle: in 1425, the gastaldi of Blato arrested a man who still smelt of roast beef for stealing a goat, ${ }^{20}$ in 1440 the gastaldi in the same village enquired into a case of two stolen sheep by checking the brands on the flocks grazing on the community territory. ${ }^{21}$ Villagers also experienced their village community as a political entity when electing legal representatives, for example to defend property rights. ${ }^{22}$ Zanin, son of Franciscus, Dragačić appears for the first time in our records as testimony in $1425 \cdot{ }^{23} \mathrm{He}$ must have been a very young man at that time, but what matters is the early integration of young peasant into local traditions of law and justice. His later career as legal expert is based on this experience "on the ground".

Villagers were also accustomed to thinking in multiple dimensions of community; this can easily be shown by analysing the importance of island law, "the customs of Korčula", which regulated contracts with herdsmen for

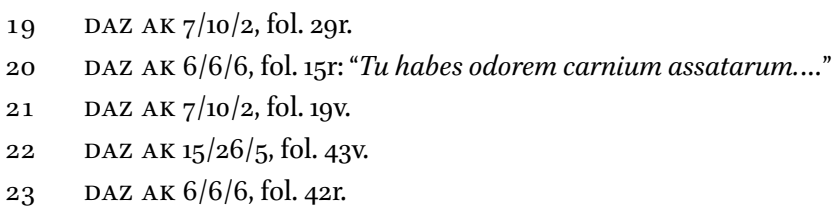


example. ${ }^{24}$ It was the island community and the Venetian governor who supervised the herdsmen's annual accounting; in 1434, controllers and pastors met in the loggia of Blato thus underlining the status of the village as an administrative centre in the rural space of Korčula. ${ }^{25}$

\section{Communities of Conflict}

In spring 1428, Zoane, son of master Kranić, had to defend himself against the accusation of having said "I do not care for the noblemen". He said that he had reacted only to the nobleman Gabriel di Antonio who had shouted on the main square: "Our slaves and our subjects, we can do everything against you, whatever we want!". Zoane responded:

You are not the count and you are not the whole of Korčula, you have no right to humiliate the poor men of Korčula, because they are not your slaves nor your subjects; they are slaves and subjects of the glorious Lordship of Venice which God may keep in a good state.

Other patricians rushed to the scene and threatened to kill the young nonpatrician, who answered:

I am not afraid of your threats because I am not guilty, and especially because I am under the domination of the glorious Lordship of Venice which does not torture any humble person against reason. ${ }^{26}$

This is certainly one of the most blatant constructions of socio-constitutional fault lines on the island in daily discourse: the same patricians who accused Venice of "tyranny" used the concept of slavery for the non-patricians. Zoane acted as representative of his community and denounced this humiliation. He responded with his own definition of belonging: he invoked the Venetian state as supreme political authority. Zoane referred to an abstract dimension of statehood and community in order to counter a concept which was based on a much more personal relation between the dominators and the dominated. The case is also an early example of how non-patricians avoided the binary social model patrician/non-patrician by introducing a new object of political loyalty

\footnotetext{
24 DAZ AK 8/11/1, fol. 181r.

25 DAZ AK $7 / 7$, fol. 9 r.

26 DAZ AK 6/6/6, fol. 127r.
} 
and communitarian belonging: being a loyal subject of the Republic of Venice and invoking its promise of impartial justice. By playing what would become the "Venetian card", non-patricians reinforced their political position.

Their claims were supported by Venice, which aimed to counteract the excessive political independence of Korčulan patricians. Venetian mediation could not prevent conflicts: indeed, around 1440, the clash between peasants and urban patricians about the discursive hegemony over the island law reached its peak. The "statuta et ordinationes" were invoked both by patricians and peasant leaders to justify their political claims before institutions of the Venetian state, i.e. its representatives on the island and the central authorities in Venice. ${ }^{27}$ In May 1441, patrician leaders claimed to defend "the good and quiet status of the community" 28 ; they characterized Korčula as a

...small homeland which has always lived in peace and love between the citizens of the island, and there has never been neither conflicts nor party struggle between the noblemen and the people.

Peace and tranquillity were disturbed by the "comunită" of some peasantspatricians used the term "community" both to denote the patrician-ruled constitutional island community and to define an opposition group (in comunità over in specialità). ${ }^{29}$ Later on, the same group is mentioned as "compagnia" under its own leaders (chavi). The patricians divided the non-patricians into loyalists and "this evil seed". 30 Among the spokesmen in the camp of the nonpatricians, Zuanin and Zanin Dragačić from the village of Čara emerged as leaders of rural communities against the patricians. In 1444, the Dragačić as "advocates of the people" (advocatores popularium ${ }^{31}$ ) gathered a village assembly (congregacion ${ }^{32}$ ) "both with those from the villages and those from the 'terra' (city)"33 in order to prepare a petition to the Venetian central authorities. The leader of the patricians, ser Forte d'Antonii, contested the legitimacy of this ensuing non-patrician delegation on the grounds that the two brothers did not represent the entire group of non-patricians. Forte constructed a new constitutional group, the "zitadini del povolo antigo", i.e. pro-patrician members of the

\footnotetext{
27 DAZ AK 7/9/I-II, fols. 16or, 182r, 194V.

28 DAZ AK $7 / 10 / 1$, fol. 3ov.

29 DAZ AK $7 / 10 / 1$, fol. 34 r.

30 Ibid.

31 DAZ AK 10/14/4 s.p.

32 DAZ Ak 10/14/4, fol. $116 \mathrm{v}$.

33 DAZ AK 10/14/4, fol. 116v.
} 
non-patrician community. ${ }^{34}$ Most interestingly, a petition from this group concluded:

we from the people of the town have always defended welfare and honour of the fatherland together with the noblemen, and now we are obliged to cover expenses together with the villagers for their business and liability for damages. ${ }^{35}$

The Dragačić reacted by stating (a) that their assembly had been convoked us usual by the peal of bells and that its participants had gathered in the Church of All Saints of Blato; (b) that previous governors had assented to these assemblies (c) that Forte's followers were illiterate and therefore unable to submit petitions against the Dragačić brothers.

We from the people always have been able to hold our assemblies, since we have been under Venetian rule, and especially since that time because our Illustrious Domination wanted that by its Council of the Pregadi [the Venetian senate] [which allowed us] to do that if we inform the governor either before or after the assembly was held.

Dragačić reminded the governor of all the assemblies held since 1420, dating them either by political events ("the attack of people from Apulia") or by the terms of Venetian governors. ${ }^{36}$ He insisted that these privileges "were not a novelty, but our old customs and tradition". Dragačić unfolded a whole programme of community building: written privileges, confirmed by the highest Venetian authorities and local constitutional traditions are invoked as sources of legitimacy, a double reinsurance of non-patrician constitutional rights of participation. A ritual of community is described in detail—church bells, the church as meeting place, the legitimacy of these assemblies.

Community was also constructed by interpreting texts or precisely by claiming the right or monopoly to read these texts. When trying to destroy Dragačić's career, the Venetian governor Marco Gradenigo was seen reading in the manuscript of the statutes and exclaiming "This chapter is against Zuanin Dragačić. ${ }^{37}$ In 1464, a quarter of a century after the violent clashes between patricians and non-patricians, the peasant leader Zuanin Dragačić, who in the meantime had

\footnotetext{
34 DAZ AK 10/14/4, fol. 168r.

35 DAZ AK 10/14/4, fol. 8a.

36 DAZ AK 10/14/4, fol. 167 r.

37 DAZ AK 10/15/3, fol. 98 r.
} 
made a splendid career as businessman, litigated with a priest. He used his defence to demonstrate his intimate knowledge of the statutes; at the same time, he linked this reference to local law with a declaration of loyalty to the Republic of Venice: "The law of Korčula, confirmed by our glorious Lordship of Venice". He then embarked on a detailed interpretation of paragraphs 36 and 37 of the statutes. ${ }^{38}$ Another process, in 1464 , opposed Dragačić to the patrician ser Mateus q. de Mixa. Dragačić invoked "our law on page 24" and declared "I want to prove by the law of Korčula which refers to real estate boundaries on page 1". These quotations from local law outraged the patrician, who tried to ridicule his non-patrician adversary: "ser Zuhanino brings in many arguments as a wise man, someone who knows the statutes, the laws, the customs and other nice legal texts" ${ }^{39}$ The patrician was unable to prevent the non-patrician homo novus from citing the statutes, but he contested his intellectual capacity to do so. However, he was quite wrong: Dragačić owed his social and political advancement to his excellent knowledge of legal procedures both on Korčula and in the Venetian state. He was well versed with the mechanisms of Venetian justice. In a process about a heritage in the village of Vela Luka, for instance, Dragačić cites a long petition to the auditori novi, the court of appeal in Venice, producing oral and written evidence from the previous forty years. ${ }^{40}$

\section{Enacting Community: Status, Gender, Public Space}

\section{Spatial Dimensions}

Patterns of social belonging were not constantly visible in daily life; but many examples point to the fact that they could be easily activated even by minor incidents. They happened in structured forms of social encounters (e.g. processions) and in spontaneous incidents. It is not by chance that the latter often took place in a symbolically charged environment such as the loggia. "Community was not only a set of institutions and a nexus of social relationships but also a particular moment in a certain kind of space". ${ }^{41}$ In the early years of Venetian administration, justice was administered by the governor and local patrician judges in the loggia; ${ }^{42}$ it was in the loggia in February 1431 that the patrician judge Marko Obradović checked a report by the priest of

\footnotetext{
$38 \quad$ DAZ AK 17 Processus doni Marci Radetini, fol. 38 r.

39 DAZ AK 18/33/3, fol. 5ov.

40 DAZ AK 18/33/16, fols. 204r, 233v-25ov.

41 Muir, "The Idea of Community", 10.

42 e.g. DAZ AK 10/14/4, fol. 18a.
} 
Čara about missing cattle-Dragačić's father, Frane, had lost two animals. ${ }^{43}$ Contracts were concluded in the loggia, but above all it was the main meeting point for patricians, a point of intense sociability, of gambling, drinking and discussing. ${ }^{44}$

The patricians regarded the loggia as their reserved social space: it was a pavilion separated from the open public space by a balustrade. The loggia was situated close to the main gate on the way to the main square of Korčula. Everyone who entered the town had to pass by. The loggia had a high potential for provoking conflict: patricians observed and commented on people coming in; on the other hand, it was easily possible to see what was going on in the loggia and to comment on it. The exclusive and at the same time communicative character of the loggia turned it into a focal point for enacting patterns of communitarian belonging, it was what Edward Muir called "the generative spaces of communities".45 In 1444 the patrician Marin Baronić overheard a quarrel between Dragačić and one of his main political enemies, the master George Grubšić ${ }^{46}$; he also observed the governor, who was likewise sitting in the loggia, stand up, insult Dragačić, and then turn to the judges who were sitting nearby and demand Dragačićs immediate condemnation. Some years later, Dragačić took his revenge: he was in the loggia when the news of a Venetian naval victory arrived and George Grubšić ridiculed it. ${ }^{47}$ When Dragačić was insulted close to the loggia by a priest because of an unpaid debt, the priest's voice could be heard "from the loggia to the city gate". ${ }^{48}$ Dragačić's sworn enemy, the Venetian governor Marco Soranzo virtually administered the island from the loggia: his conflict with his Venetian fellow patrician Francesco Lombardo aroused the curiosity of many bystanders: Soranzo who had refused to store Lombardo's grain cargo in the communal warehouse shouted: "Don't you know who you are in Venice? You are a damned liar if you want to imprison me in Venice". The ensuing trial allows us to reconstruct the people who frequented the loggia: there were Pietro Riverio from Chioogia, Jacobo da Trani, an inhabitant of Korčula, Bartolomeo de Ursis, whose father sold spices in the contrata S. Polo in Venice, the Korčulan nobleman Nikola Petrović, Nikola Ivanović, a servant of a Bosnian nobleman (who was declared to have been too

\footnotetext{
43 DAZ AK 6/3/8, fol. 6r.

44 In 1477, a prohibition "ludere de Dio ad aliquod ludum alobi qual sub lobia comunis et ad marinam et ad muros extra civitate" was proclaimed in Korčula. DAZ AK 25/48/2, fol. 1 .

45 Muir, "The Idea of Community", 10.

46 DAZ AK 12/20/1 s.p.

47 DAZ AK $13 / 22 / 3$, fol. 366r-v.

48 DAZ AK 15/29/4, fol. 24r.
} 
occupied playing cards, "ponebat mentem ludere ad cartas") and Frane Marsić, a wealthy Korčulan priest. ${ }^{49}$ The loggia was an Adriatic meeting place for men from the metropolis, from Apulia and the neighbouring Balkans. It was where peasants like the Dragačići became acquainted with the outside world, political news, information about Venetian justice and state apparatus. It was also the place where the Dragačići enacted their role as leaders of the non-patricians.

In February 1456, Zanin Dragačić was passing by the loggia when he saw the gastaldi taking an arrested man, who was obviously one of his acquaintances, to prison. He opposed his arrest. Many patricians who were playing games observed this quarrel. They immediately rushed to the scene and accused him of obstructing public justice. Within a very short time, the incident mobilized patricians and non-patricians, partisans of both groups gathered and the quarrel degenerated into an exchange of severe accusations with "very rude words", and eventually both sides became violent.

You have ever been the enemies of the noblemen of this place and you have always wanted to destroy them. ...you want to protect thieves because you have built a house out of the blood of this people which you have swallowed. ...you should not obstruct justice.

were some of the patricians' arguments; they even accused Dragačić of planning to murder the governor. Dragačić replied "You will get to know me, if I go to Venice". ${ }^{50}$

\section{Traditional Socio-Cultural Structures}

Processions made social belonging and social differences perceptible. Processions also mirrored social and gender status: first male patricians, secondly male non-patricians, in the third place female patricians. In February 1460 , three non-patricians marched in front of the female patricians. A nonpatrician tried to correct a patrician lady, in Slavic as is expressly remarked: " $D o$ not say the credo now, say the paternoster". The lady was outraged because of what she perceived as insult and replied: "What the hell, do you dare to approach noble ladies, why don't you go on your own way?" The man replied: "I do not want to have anything to do with you. I will not speak with you, may bad blood come upon you".51 The procession as embodiment of social and gender hierarchy

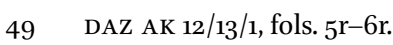

50 DAZ AK 14/25/17, fol. 1or.

51 DAZ AK $15 / 29 / 5$, fol. 22 . 
could be turned into a scene of struggle about cultural prestige and social contest: by correcting the patrician lady, the non-patrician man was constructing a symbolic superiority; the lady opposed her own definition of social status linked with gender to this transgression. Thus targeting women as supposedly weaker members of competing communities was not unusual on Korčula. Patricians attempted to destroy the political career of Zuanin Dragačić by denouncing him as a violator and later on by denigrating his mistress Franuša as a "whore". 52

These examples demonstrate how minor conflicts could quickly turn into a conflict between communities and over political principles. Decades of political strife were recalled, fears of violence and total annihilation appear as an immediate reaction on the part of the patricians. Korčulans were extremely sensitive where questions of belonging to the main categories patricians/nonpatricians were concerned. A deep consciousness of belonging could be activated at any moment, a feeling that was closely linked to concepts of honour and pride.

Community was constructed on both sides by a highly emotional discourse ("we" and the "other", existential fears) which pointed to basic questions as implementation of justice, conflicts between groups which were explicitly named (noblemen vs people) and the importance of Venice as the mediating power and supreme authority on the island.

\section{An Island Community? Patterns of Othering on Korčula}

\section{a) Others within}

Patricians and non-patricians had one thing in common - they belonged to communities which were defined in the city statutes as constitutional groups. Building community also implies also a process of seclusion and exclusion. Patricians excluded non-patricians, non-patricians in the rural area excluded people who did not belong to the village (but they included patricians living in their village!); there were socio-economic communities with their own bonds of mutual loyalty and solidarity, such as clergymen, pastors, and fishermen, but the all were part of the island community which acted as a political entity in cases of emergency. There was no Jewish community on the island, nor any other non-Catholic religious group. There were no differing linguistic communities either, nor were there any sizable groups of excluded people such as beggars or lepers. Othering had therefore to refer to "strangers" or "outsiders" (forenses, forestieri), people from the Adriatic world and the Balkan hinterland of Korčula. 


\section{b) The Close "Other"}

Traditional historiography has very much concentrated on "class struggles" between patricians and non-patricians. It rather overlooked cases where the islanders as a community opposed what they perceived as foreign intrusion. This solidarity bridged structural conflicts on the island. It could be activated in minor conflicts or in major riots if islanders felt a spontaneous consensus on how to assess the behaviour of those who were "outsiders". There were basically two types of foreigner on Korčula: a rather small group permanent residents (habitatores), and people who were passing through, both legally (mainly seamen and traders) and illegally (robbers, illegal woodcutters from Dubrovnik, pirates, and escaped slaves).

Korčula was very much exposed to raids from the neighbouring mainland, the Krajina. Men from Krajina often crossed the narrow Korčula Channel and committed serious robberies in the rural hinterland. Since all Korčulans were concerned, socio-political differences disappeared in the common defence of economic interests against "foreigners". ${ }^{3}$ Islanders organized naval patrols, they warned one another when men from Krajina crossed the channel, and they also kept watch over the coastline. There was another neighbour who was considered to be much more dangerous: the Republic of Dubrovnik. In fact, since 1420, an international sea border ran between Korčula and the nearby peninsula of Pelješac. These waters were troubled by smugglers, corsairs and the competition between Korčulan and Dubrovnik fishermen. There were many clashes between the fishermen, especially at night, and confronting people from Dubrovnik very much contributed to the patterns of identification of an island community. Korčulans also emphasized Venice's obligation to protect them - this maritime protection was probably one of the most important advantages of Venetian rule for the entire island community. In the 15th century corsairs and maritime enemies, mainly Catalans operating from the Kingdom of Naples, were also perceived as threat to the whole communityan attack by a Neapolitan fleet mobilized this island solidarity and blurred differences between patricians, non-patricians and foreigners living in Korčula. Smuggling was a two-edged sword in the sense that Venice defined it as a crime, which meant that traditional Korčulan trade with the Neretva valley in Herzegovina or with Apulia suddenly came under a legal ban. Leading Korčulan patricians were involved in what Venice considered as smuggling, and some of them even delivered arms to the Ottomans during the Veneto-Ottoman wars. ${ }^{54}$ Venice was unable to punish these crimes, because of the high social status of

53 DAZ AK 6/6/6, fol. 27v.

54 Schmitt, "Contrabannum”. 
many of the wrongdoers, whose support it needed for administering the island. Korčulan smugglers and their crews certainly functioned as close-knit communities, but they were never excluded by their fellow Korčulans even if denunciations were not rare; but these had to do with interpersonal conflicts.

\section{c) "Foreigners" from Far Away}

There were never many Venetians on the island, but those who remained in Korčula for some time enjoyed special prestige. Their behaviour was closely observed, however, especially when female honour seemed to be in danger. Six years after the contract with Venice, a Korčulan surprised some young Venetian noblemen harassing a young local girl in the church of St Michael. He tried to reprimand them, first respectfully, "You who are wise are not doing well", then accusing them directly of violation. The young patricians responded with insults and counter-accusations. ${ }^{55}$ Venetian patricians often stopped over on Korčula, but usually they left no trace-cases of shipwreck excluded. The number of Venetian patricians doing business on the island was rather limited. Nevertheless, frictions between Korčulans and Venetians did occur; in June 1458, the "youth of the community" (multa iuventus comunitatis) quarrelled with the Venetian patrician Lodovico Contarini; on that occasion, the patrician ser Antonius Stanoe called the Venetians "worthless men". ${ }^{56}$

The only group of Venetians that had a permanent impact on the island society were the governors and their small administrative staff-they were perceived both as individuals and as representatives of the Venetian state. They constituted the institutionalized, but powerful political "other" on the island. All constitutional communities tried to establish special relations with them, and the Venetian system of office rotation opened a regular opportunity for renegotiating these relations. Negotiating was very much a reciprocal process, because Venetian governors usually had no detailed knowledge of the island community they had to administrate and therefore were dependent on local information. This dependency and commercial interests induced some governors to lean towards local political communities, thus exacerbating socio-political strife on the island. ${ }^{57}$ Local political leaders attempted to play off governors against their local adversaries. The behaviour of Venetian governors thus contributed essentially to the process of building and maintaining communities bonds. Venetian central authorities, on the other hand, tried to

\footnotetext{
55 DAZ AK 6/6/6, fol. 32v.

56 DAZ AK 15/29/3, fol. 497v: "redundant in despectum vilipendium et contemptum Nostri Illustrissimi dominii et magistratus et regiminis ipsius domini comitis".

57 This was the case with Dragačićs adversaries Marco Soranzo or Marco Gradenigo.
} 
placate communitarian tensions on the island. Distinguishing between these two contradictory effects of Venetian rule is essential in assessing the Venetian factor in local communitarian processes of identification. Protest delegations to Venice and visits by Venetian state controllers to the island both served as outlets for dissent. They also made an essential contribution to the discursive negotiation of the governors' position in local society. The preparation and composition of these protest delegations was a constant bone of contentionpatricians contested the non-patricians' right to send embassies to Venice, non-patricians on the other hand used preparative assemblies as a tool for raising the profile of their community. The Dragačic brothers played an essential part in this process. ${ }^{58}$ They were prominent among those who insulted and intimidated Venetian governors because of their alleged or real pro-patrician position or because of what they perceived as misconduct. ${ }^{59}$

Venice was also present on the island in another hypostasis: it increasingly emphasised the election of Venetian patricians as bishops of Korčula; a process a slow Venetianization of church hierarchies took place throughout the Venetian overseas empire. Venetians thus controlled the two most prestigious positions on the island. The bishop, however, did not consider himself as representative of the Venetian state, and his power base on the island was quite different from the resources of the governors. The bishops held sway over the island clergy and ecclesiastical property. Thus they were directly involved in internal economic and social networks of Korčula. Since their presence on the island was in principle not limited, conflicts between the bishop and parts of the local society had a much higher potential for escalation.

\section{A Case Study: Layers of Belonging in an Island Community—The Riot Against the Venetian Bishop in October $145^{8}$}

In the 145 os, the Venetian patrician Luca Leon served as bishop of Korčula. Soon after his arrival on the island, he began to increase taxes and to centralize Church property under his personal control. He quickly made many enemies on the islands - clergymen who in June 1457 refused to pay, ${ }^{60}$ patricians and even pastors, whom he obliged to pay higher tithes. This economic threat united all flock owners, patricians and the peasant leader Zuanin Dragačić. ${ }^{61}$

\footnotetext{
58 DAZ AK $9 / 2 / 2$, fol. 63 r; 10/14/4, fol. 1r.

59 DAZ AK $15 / 29 / 3$, fols. 514 r; $524 \mathrm{~V}-525$ r.

6o DAZ AK 15/29/4, fol. 44 r.

61 DAZ AK $15 / 26 / 5$, fol. $42 \mathrm{v}$.
} 
When they agreed to send a protest delegation to Venice, the governor stopped them in the port of Korčula under the pretext that they had not previously shown him their letter of complaint. ${ }^{62}$ The conflict with the island clergymen reached its peak when Leon tried to seize the possessions of an extremely wealthy village priest, whose nephew, a priest himself, refused to hand over his uncle's property. ${ }^{63}$

Resentment against the bishop exploded on 4 October $145^{8}$, when a local priest refused to pay the tithe. The bishop started beating the priest and tore his clothes to pieces. The priest rushed to a window of the bishop's palace, threw his priestly robes into the main square and called some of his patricians friends to his help. Within a few moments, rumours were circulating in the narrow streets of Korčula and people ran to the palace. An angry crowd besieged the bishop, while the priest escaped through a kitchen window. When the bishop tried to follow him, he was surrounded by the crowd which shouted at him accusations as "You keep whores, thieves and bastards in your house, and this is the reason for these evil things. ...You keep bastards in your house, and this dishonours honest people". Particular hatred was directed against Don Feliciano, the bishop's illegitimate son who served as his notary. People touched the person of the bishop, although they did not dare assault him directly. ${ }^{64}$

Gender, age and social status played an essential role in the interpretation of the uproar. When the governor investigated the events, many patrician witnesses asserted the leading role of women in spreading rumours and provoking the upheaval. Others declared that they suspected the bishop of beating women and that this time people had wanted to react. Only after non-patrician women had stirred up public unrest, were the patricians obliged to play a leading role. Patrician and non-patrician witnesses insisted on violent acts perpetrated by the bishop and his bastard son, who had both beaten up a patrician and other enemies of the bishop. Once again, Zuanin Dragačić was part of the events. He said that he was informed about the incident in the bishop's palace by the wife of a cooper, and that he had tried to calm down a cowgirl called Anica, saying: "Be quiet, the bishop is helping you and your children, and you are screaming!" ${ }^{65}$ According to male patricians, the crowd on the main square was made up of many women, and the bishop added that women had helped the priest to escape through the window.

\footnotetext{
62 ibid. fol. $52 \mathrm{~V} 29$ th October 1457.

63 DAZ AK 17/32/3, fol. \$: "Copia processus facti contra Antonium Marsich per Reverendum patrem dominum episcopum”.

64 DAZ AK $15 / 29 / 3$, fol. 508-513r.

65 DAZ AK 15/29/3, fol. 509v.
} 
It is obvious that the senior patricians and peasant leaders understood how serious the investigation was, which is why they tried to reinterpret the events as an unimportant and spontaneous uproar by women and young patricianssons and sons-in-law of leading men, people without social prestige and political importance. They did everything to downplay their own role, especially as one of them had been seen with a sword, and carrying arms in the town was a clear sign of open rebellion, not against the bishop but against the authority of Venetian rule. Dragačić, who as an owner of cattle had grudge against the bishop, carefully presented himself as defender of public order. Many patricians had every reason to hide their actual role in the uproar: the Obradović and Paperčić clans belonged to the political and social elite of the island. The man with the sword was Nicolaus Quarussich, father-in-law of the protestleader Marinus Paperčić, whose wife was the sister of a late archdeacon. ${ }^{66}$

The uproar physically united people from different constitutional communities and at a first glance expressed the opposition of at least the urban community to the bishop - a closer analysis however reveals that personal interests were behind the protest. Dragačićs role is quite telling: although he shared economic interests with patricians involved in the affair, he avoided supporting them in public. Once the affair had degenerated into something that could be interpreted as rebellion, the patricians tried to shift responsibility onto people with lesser social status.

\section{Conclusion}

Korčula is not an exceptional case. On the contrary, it fits into the long research discussion on civic communities mainly in late medieval Italy. It is exceptional only because of its extraordinary archival documentation. Community is a key concept for understanding social fault lines on this island. The main divisions between patricians and non-patricians were not just on paper but had a great potential for social and political mobilization. Korčulan society was extremely thin-skinned as far as belonging to these constitutional communities was concerned, and minor incidents could stir up serious uproar where belonging to community materialized in a gathering of people, in speech acts and body language. Community was enacted in public space, and the latter was "branded" by competing communities. Community was enacted in institutions by means of inclusion and exclusion but also by protest and contention. Community was 
constructed very much by addressing "outsiders" such as the Venetian state and its central and local representatives. Invoking community did not just help to define one's place in society, it also expressed personal relations and personal interests that where conveyed in a communitarian discourse. Edward Muir sees in communities a network of "thin trust" where networks of "thick trust" were able to recruit new loyalties. In a small and manageable society such as Korčula the difference between "thick trust" based on intimate personal knowledge and "thin trust" encompassing a whole community however cannot always easily be drawn.

\section{Bibliography}

Gerhard Dilcher, "Verschriftlichung und Wandlungen der Normstruktur in den Stadtrechten des 12. und 13. Jahrhunderts", in Pragmatische Schriftlichkeit im Mittelalter: Erscheinungsformen und Entwicklungsstufen, eds. Hagen Keller, Klaus Grubmüller and Nikolaus Steinbach (Munich, 1992), 9-19.

Serđo Dokoza, Dinamika otočnog prostora (Split, 2009).

John V.A. Fine, When ethnicity did not matter: A Study of Identity in Pre-Nationalist Croatia, Dalmatia, and Slavonia in the Medieval and Early-Modern Periods (Michigan, 2006).

Vinko Foretić, "Borbe između pučana i plemića na Korčuli u 15. i 16. stoljeću", Sveučilište u Zagrebu - Institut za hrvatsku povijest. Radovi 10 (1977), 249-74.

Mario Gentile, "Factions and Parties: Problems and Perspectives", in The Italian Renaissance State, eds. Andrea Gamberini and Isabella Lazzarini (Cambridge, 2012), 304-22.

Hagen Keller, "Die Veränderung gesellschaftlichen Handelns und die Verschriftlichung der Administration in den italienischen Stadtkommunen", in Pragmatische Schriftlichkeit im Mittelalter: Erscheinungsformen und Entwicklungsstufen, eds. Hagen Keller, Klaus Grubmüller and Nikolaus Steinbach (Munich, 1992), 21-36.

Hagen Keller, Klaus Grubmüller and Nikolaus Steinbach, eds., Pragmatische Schriftlichkeit im Mittelalter: Erscheinungsformen und Entwicklungsstufen (Munich, 1992).

Arie Malz, "Frühneuzeitliche Modernisierung als Sackgasse: Die dalmatinische Städtewelt vom 14. bis zum 18. Jahrhundert", in Städte im östlichen Europa, eds. Carsten Goehrke and Bianka Pietrow-Ennker (Zurich, 2006), 103-33.

Reinhold C. Mueller, "Aspects of Venetian Sovereignty in Medieval and Renaissance Dalmatia", in Quattrocento adriatico: Fifteenth century art of the Adriatic rim, ed. Charles Dempsey (Bologna, 1996), 29-56.

Edward Muir, "The Idea of Community in Renaissance Italy", Renaissance Quarterly 55 (2002), 1-18. 
Monique O'Connell, Men of Empire (Baltimore, 2009).

Ermanno Orlando, Gli accordi con Curzola (Rome, 2002).

Gherardo Ortalli, "Il ruolo degli statuti tra autonomie e dipendenze: Curzola e il dominio veneziano", Rivista storica italiana 98,1 (1986), 195-220.

Gherardo Ortalli and Oliver Jens Schmitt, eds., Balcani occidentali, Adriatico e Venezia fra XIII e XVIII secolo (Vienna, 2009).

Gherardo Ortalli, Oliver Jens Schmitt and Ermanno Orlando, eds., Il Commonwealth veneziano tra 1204 e la fine della Repubblica: Identità e peculiarità (Venezia, 2015).

Claudio Povolo, "Liturgies of Violence: Social Control and Power Relationships in the Republic of Venice between the 16th and 18th Centuries", in Companion to Venetian History, ed. Eric R. Dursteler, Brill's Companions to European History (Leiden, 2013), 513-42.

Vinko Pribojević/Vincentius Priboevius, O podrijetlu i zgodama Slavena/Oratio de origine successibusque Slavorum, eds. Grga Novak and Veljko Gortan (Zagreb, 1951).

Oliver Jens Schmitt, "Contrabannum: Der adriatisch-balkanische Schmuggel im ausgehenden Mittelalter", Südost-Forschungen 67 (2008), 1-26.

Oliver Jens Schmitt, Korčula sous la domination de Venise au 15e siècle, Les conférences du Collège de France (Paris, 2011); e-book http://conferences-cdf.revues.org/.

Oliver Jens Schmitt, "Storie d'amore, storie di potere-la tormentata integrazione dell'isola di Korčula/Curzola nello Stato da mar", in Venezia e Dalmazia, eds. Uwe Israel and Oliver Jens Schmitt (Rome, 2013), 89-109.

Ludwig Steindorff, Die dalmatinischen Städte im 12. Jahrhundert: Studien zu ihrer politischen Stellung und gesellschaftlichen Entwicklung, Städteforschung, Veröffentlichungen des Instituts für vergleichende Städteforschung in Münster A 20 (Cologne, Vienna, 1984).

Ludwig Steindorff, "Privilegien als Ausdruck kommunaler Emanzipation: Der Fall Šibenik”, in Grafenauerjev zbornik, ed. Vincenc Rajšp (Ljubljana, 1996), 391-402. 